○青柳 優, 横田雅司, 鈴木 壹, 榊原 昭, 渡辺知緒, 伊藤 吏 山形大学耳鼻咽喉科

\title{
【はじめに】
}

我々は $80 \mathrm{~Hz}$ 変調周波数追随反応 ( $80 \mathrm{HzAMF} \mathrm{R}$ ) が睡眠時の幼児に対する他覚的聴力検查 法として有用であることを報告してきたが、今回は難聴幼児125例において聴力レベルと $80 \mathrm{~Hz}$ AMFR反応閾値を比較して $80 \mathrm{HzAMFR}$ 有用性について再度検討した。又、滲出 性中耳炎や心因性難聴における80HzAMFRの応用について報告する。

【対象と方法】

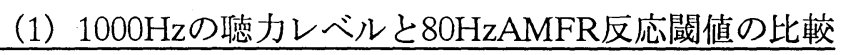

難聴幼児125名169耳 (3歳〜15歳、平均5歳9月) を対象として $1000 \mathrm{~Hz}$ の聴カレベルと $\mathrm{ABR}$

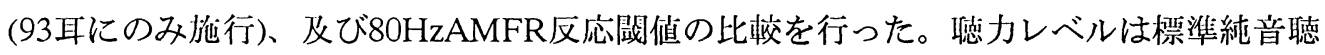
力検查により求めたが、5歳以下の児では遊戯聴力㭘査により求めた例もあった。 ABR と80HzAMFRは亚服時に下記のように検查した。

80Hz AMFR : 刺激音はファンクションジェネレータ (NF Model FG-163) 2機を組み合わ せて作り、刺激信号発生装蹎 (DANAC 502A) を介して音圧を定め、ヘッドフォーン (TDH-49) により与えた。変調周波数は $80 \mathrm{~Hz}$ 、搬送周波数は $1000 \mathrm{~Hz}$ 、変調度は95\%とし た。記録はシグナルプロセッサ7T18A (NEC三栄) を用い、フィルタは8〜300 Hzとして 頭頂部一耳垂より記録した。サンプリング点数は512点、解析時間は204.8ms、周波数分 析能は4.9 Hzとした。反応閾值はCSMの基準値を 0.385 として自作の位相スペクトル解析 プログラムにより自動判定にて求めた。

ABR : 刺激音は $1000 \mathrm{~Hz}$ のトーンピップ (2-1-2) を刺激間隔53msにて同じヘッドフォーン により与えた。フィルタは80〜 $1500 \mathrm{~Hz}$ 、解析時間は $20.48 \mathrm{~ms}$ とした。

(2) 同波数特置性についての検討

上記125例のうちオージオグラムの得られた難聴幼児26例27耳においては、前項の検討と 別に搬送周波数を500、1000、2000、4000 Hzに変えて $80 \mathrm{~Hz}$ AMFR閾值を求め、各々の才

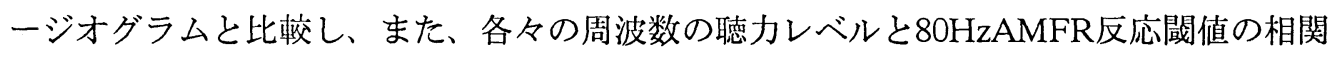

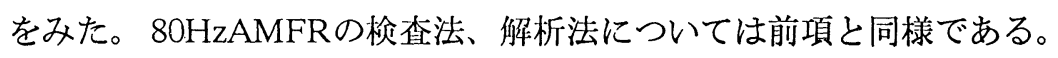

（3）滲出性中耳炎と心因性難聴における臨床応用

沴出性中耳炎2例 (いずれも3歳、男児) における鼓膜チューブ留置前後の聴力検査、及び 心因性難聴2例 (いずれも10歳、女児) における聴力検査として $80 \mathrm{~Hz}$ AMFRとクリック音 によるABRを用いた結果について検傠した。

\section{【結 呆】}

(1) 恥力レベルとABR及び $80 \mathrm{~Hz}$ AMFRの反応閾値の比較

$1 \mathrm{kHz}$ の恥力レベルとの差は、ABRで平均 $8.8 \mathrm{~dB}$ (標準偏差 $14.1 \mathrm{~dB}$ )、80 Hz AMFRで3.8dB (標準偏差 $12.9 \mathrm{~dB}$ ) であり、 $80 \mathrm{~Hz}$ AMFRの方が有意に聴力レベルに近かった $(\mathrm{p}<0.05)$ 。 また、ABR閾值と聴力レベルの相関係数 (0.828) より $80 \mathrm{~Hz}$ AMFR閾值と聴カレベルの相 関係数 (0.863) の方が大きく、 $80 \mathrm{~Hz}$ AMFRの方がより正確に聴力レベルを反映している ことが示された。 
500〜 4000Hzにおいて $80 \mathrm{~Hz}$ AMFR閾值と聴力レベルの相関係数を比較すると、 $500 \mathrm{~Hz}$ は0.729 ( $=34) 、 1000 \mathrm{~Hz} 0.863(n=169) 、 2000 \mathrm{~Hz}$ は0.931 $(n=30) 、 4000 \mathrm{~Hz}$ は0.819 $(n=13)$ と、周波数の高いほど相関計数が高い傾向にあった。

(2) 周波数特異性についての検討（図）

各搬送周波数ごとの $80 \mathrm{~Hz}$ AMFR閾值を各々のオージオグラムに重ね合わせて見ると、 $80 \mathrm{~Hz}$ AMFR閾值はオージオグラムと良く一致したパターンを示し、幼児において $80 \mathrm{~Hz}$ AMFRは周波数特異性の高いことが判った。

（3）沴出性中耳炎と心因性難聴における臨床応用

渗出性中耳炎2例では鼓膜チューブ留置前後の検查においてABRでは変化を認めなかった が、80Hz AMFR閾値は留置後500〜2000Hzにおいて閾值の改善が認められた。1例では チューブ悦落後の検查で $80 \mathrm{~Hz}$ AMFR閾值、及びABRに閾值の上昇が認められた。

心因性難恥2例は純音聴力検查ではいずれも高度の水平性感音難聴を示したが、 $500 \mathrm{~Hz}$ と $1000 \mathrm{~Hz}$ の $80 \mathrm{~Hz}$ AMFR閾值は10〜30dB、ABR閾值は0〜10dBであることから正常聴力 と判定された。

\section{【結 論】}

位相スペクトル解析により判定した場合、 $80 \mathrm{~Hz}$ AMFRは唾呡時の幼児において他覚的聴 力検查として周波数特異性の高い㭘査法であり、これにより聴力レベル、及び聴力像が かなり正確に推定できる。

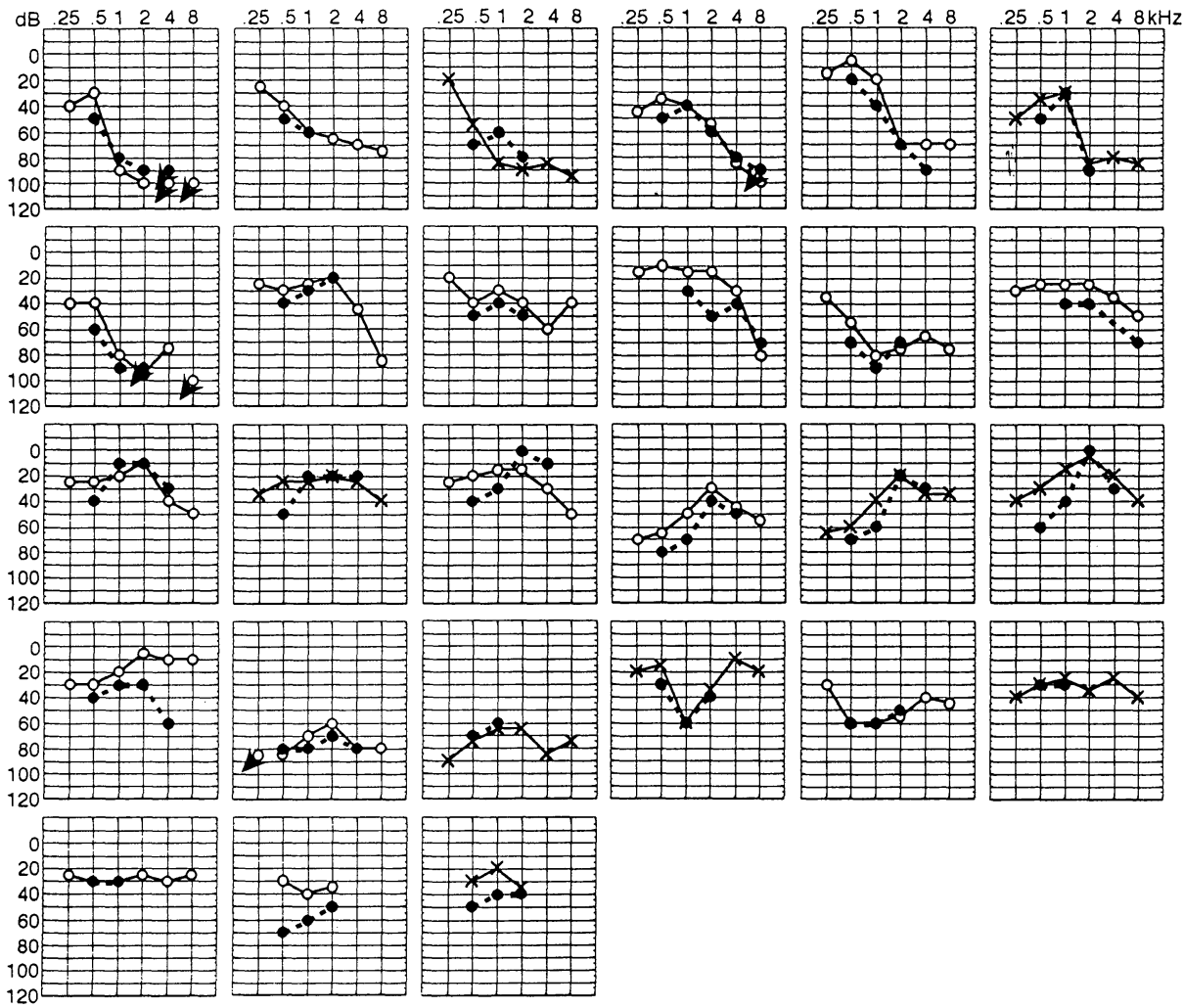

図 : 難聴幼児26例27耳におけるオージオグラムと80HzAMFR閾值（○）の比較。 